\title{
Biogenesis of the mitochondrial phosphate carrier
}

\author{
Vincenzo ZARA ${ }^{1}$, Joachim RASSOW ${ }^{2}$, Elmar WACHTER ${ }^{2}$, Maximilian TROPSCHUG ${ }^{2}$, Ferdinando PALMIERI ${ }^{1}$, Walter NEUPERT ${ }^{2}$ \\ and Nikolaus PFANNER ${ }^{2}$ \\ 1 Dipartimento Farmaco-Biologico, Laboratorio di Biochimica, Università di Bari, Italy \\ 2 Institut für Physiologische Chemie, Universität München, Federal Republic of Germany \\ (Received January 9, 1991) - EJB 910061
}

\begin{abstract}
The mitochondrial phosphate carrier $\left(\mathrm{P}_{\mathrm{i}} \mathrm{C}\right)$ is a member of the family of inner-membrane carrier proteins which are generally synthesized without a cleavable presequence. Surprisingly, the cDNA sequences of bovine and rat $\mathrm{P}_{\mathrm{i}} \mathrm{C}$ suggested the existence of an amino-terminal extension sequence in the precursor of $\mathrm{P}_{\mathrm{i}} \mathrm{C}$. By expressing $\mathrm{P}_{\mathrm{i}} \mathrm{C}$ in vitro, we found that $\mathrm{P}_{\mathrm{i}} \mathrm{C}$ is indeed synthesized as a larger precursor. This precursor was imported and proteolytically processed by mitochondria, whereby the correct amino-terminus of the mature protein was generated. Import of $\mathrm{P}_{\mathrm{i}} \mathrm{C}$ showed the characteristics of mitochondrial protein uptake, such as dependence on ATP and a membrane potential and involvement of contact sites between mitochondrial outer and inner membranes. The precursor imported in vitro was correctly assembled into the functional form, demonstrating that the authentic import and assembly pathway of $\mathrm{P}_{\mathrm{i}} \mathrm{C}$ was reconstituted when starting with the presequence-carrying precursor. These results are discussed in connection with the recently postulated role of $\mathrm{P}_{\mathrm{i}} \mathrm{C}$ as an import receptor located in the outer membrane.
\end{abstract}

The mitochondrial inner membrane contains at least nine transport systems (carriers) for metabolites [1 - 4]. This carrier family includes the ADP/ATP carrier, the uncoupling protein, the phosphate carrier $\left(\mathrm{P}_{\mathrm{i}} \mathrm{C}\right)$, and the oxoglutarate carrier. The primary structures of these proteins were determined by amino acid sequence analysis or by cDNA sequencing [5-8]. These carrier proteins are about 300 amino acid residues in length and are strongly related in amino acid sequence and structure. Each carrier consists of three homologous repeats of about 100 amino acid residues, implying that the carrier proteins are derived from a common ancestor gene that originally coded for a protein of about 100 amino acid residues.

Most mitochondrial precursor proteins that are translocated into or across the inner membrane are synthesized with amino-terminal targeting sequences (presequences) that are cleaved off by processing peptidase in the matrix $[9,10]$. The precursors of the ADP/ATP carrier, the uncoupling protein, and the oxoglutarate carrier, however, were found not to carry a presequence $[8,11-15]$. This demonstrated that these proteins of the carrier family contained all the targeting information in the mature protein sequence. It was therefore very surprising that the amino acid sequence of mammalian $\mathrm{P}_{\mathrm{i}} \mathrm{C}$, predicted from the nucleotide sequences of bovine and rat cDNA $[7,16]$, suggested the existence of an amino-terminal extension sequence not present in the mature protein. This presequence exhibits general features of mitochondrial presequences, in particular a high content of positively charged amino acid residues. In this study we asked whether $\mathrm{P}_{\mathrm{i}} \mathrm{C}$ is

Correspondence to N. Pfanner, Institut für Physiologische Chemie, Universität München, Goethestrasse 33, W-8000 München 2, Federal Republic of Germany

Abbreviation. $\mathrm{P}_{\mathrm{i}} \mathrm{C}$, phosphate carrier.

Enzyme. Proteinase K (EC 3.4.21.14). indeed synthesized and imported as a larger precursor. We expressed the presequence-carrying form in vitro and found that it was specifically imported and processed by isolated mitochondria. $\mathrm{P}_{\mathrm{i}} \mathrm{C}$ imported in vitro was correctly assembled, demonstrating that the authentic import of $\mathrm{P}_{\mathrm{i}} \mathrm{C}$ was reconstituted.

Recently it was found that a putative import receptor, p32 of yeast mitochondria (which should be an outer-membrane protein), is related in primary sequence to mammalian $\mathrm{P}_{\mathrm{i}} \mathrm{C}$ $[17,18]$ and obviously identical to yeast $\mathrm{P}_{\mathrm{i}} \mathrm{C}[19,20]$. Therefore, the localization of cloned $\mathrm{P}_{\mathrm{i}} \mathrm{C}$ in the inner-mitochondrial membrane and their function as $\mathrm{P}_{\mathrm{i}} \mathrm{C}$ were questioned. We show here that the import of bovine $\mathrm{P}_{\mathrm{i}} \mathrm{C}$ involves specific cleavage of a presequence and requires the membrane potential $(\Delta \Psi)$ across the inner membrane, strongly arguing against $\mathrm{P}_{\mathrm{i}} \mathrm{C}$ being an outer-membrane protein $[9,21] . \mathrm{P}_{\mathrm{i}} \mathrm{C}$ imported in vitro acquires specific properties of the native $\mathrm{P}_{\mathrm{i}} \mathrm{C}$, demonstrating that the correct $\mathrm{P}_{\mathrm{i}} \mathrm{C}$ was cloned. Our findings present interesting implications for the function of the p32 import receptor.

\section{EXPERIMENTAL PROCEDURES}

Subcloning and in vitro expression of bovine $P_{i} C$

A cDNA clone of bovine $\mathrm{P}_{\mathrm{j}} \mathrm{C}$ in pUC8 [7], kindly provided by Dr. J. E. Walker (MRC, Cambridge, UK), was cut with $B a m \mathrm{HI}$ and $B g I \mathrm{I}$. The resulting segment $(2.7 \mathrm{~kb})$, containing the entire coding region (plus a piece of pUC8), was treated with $\mathrm{S} 1$ nuclease and Klenow polymerase and cloned into a SmaI-cut pGEM4 transcription vector (Promega) [22], resulting in plasmid $\mathrm{pGEM} 4 / \mathrm{P}_{\mathrm{i}} \mathrm{C}$ (Fig. $1 \mathrm{~A}$ ). Insertion was confirmed by sequencing with SP6-specific and T7-specific primers. In vitro transcription with SP6 RNA polymerase and subsequent translation of the capped RNA in reticulocyte 
A

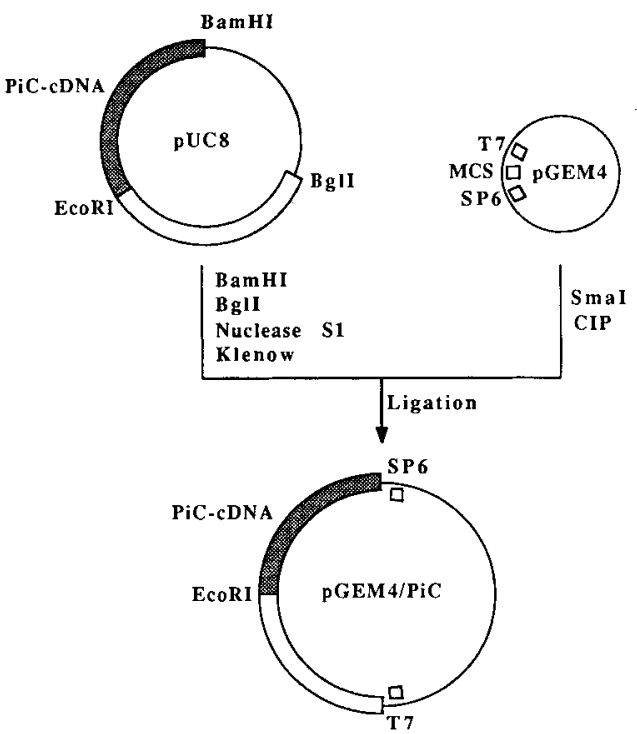

B $\quad 1 \quad 2 \quad 3$

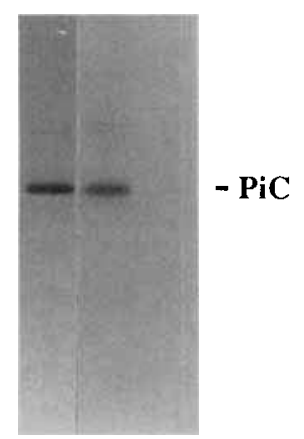

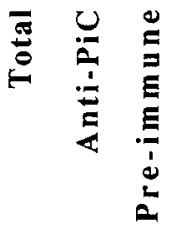

Fig. 1. Expression of the precursor of $P_{i} C$. (A) Construction of an in vitro expression vector for $\mathrm{P}_{\mathrm{i}} \mathrm{C}$. (B) In vitro expression of $\mathrm{P}_{\mathrm{i}} \mathrm{C}$ precursor. Protein synthesis was carried out in a rabbit reticulocyte lysate in the presence of $\left[{ }^{35}\right.$ S]methionine and $\mathrm{P}_{\mathrm{i}} \mathrm{C} \mathrm{mRNA}$, derived from the transcription system pGEM4, for $60 \mathrm{~min}$ at $30^{\circ} \mathrm{C}$. Sample 1 (control), $1 \mu \mathrm{l}$ postribosomal supernatant. Samples 2 and 3 ( $\left.1 \mu \mathrm{l}\right)$ were subjected to immunoprecipitation with antiserum specific for $\mathrm{P}_{\mathrm{i}} \mathrm{C}$ (sample 2) or preimmune serum (lane 3) using protein-A - Sepharose. The control and the immunoprecipitates were analysed by SDS/PAGE and fluorography. MCS, multiple-cloning site; CIP, calf intestinal phosphatase

lysates [23] resulted in a $\mathrm{P}_{\mathrm{i}} \mathrm{C}$ precursor with an apparent molecular mass of $38 \mathrm{kDa}$ on SDS/PAGE.

\section{Preparation of mitochondria}

Bovine heart and rat liver mitochondria were prepared as described previously [24, 25]. Published procedures were used for the isolation of mitochondria from Neurospora crassa $[26,27]$ and Saccharomyces cerevisiae $[28,29]$.

\section{Import of $P_{i} C$ into isolated mitochondria}

Isolated mitochondria ( $50 \mu \mathrm{g}$ protein) were incubated in buffer A (250 mM sucrose, $80 \mathrm{mM} \mathrm{KCl}, 5 \mathrm{mM} \mathrm{MgCl}_{2}$, $10 \mathrm{mM}$ Mops and 3\% (mass/vol.) bovine serum albumin, adjusted to $\mathrm{pH} 7.2$ with $\mathrm{KOH}[27]$ ) and $20 \%$ (by vol.) reticulocyte lysate containing the radiolabeled precursor of $\mathrm{P}_{\mathrm{i}} \mathrm{C}$ in a final volume of $100 \mu \mathrm{l}$. NADH (Sigma; $2 \mathrm{mM}$ final concentration) was added from a 50 -fold-concentrated stock solution in water. Valinomycin and oligomycin (Sigma; $1 \mu \mathrm{M}$ and $20 \mu \mathrm{M}$ final concentrations, respectively) were added from a 100 -fold-concentrated stock solution in ethanol. The samples were made chemically identical by adding the same amount of reagent-free solvent to the control samples. The duration and temperature of the incubations are given in the figure legends. For protease treatment, the samples were cooled to $0^{\circ} \mathrm{C}$ and proteinase $\mathrm{K}$ (20 units/mg; Boehringer Mannheim) was added. After incubation for $20 \mathrm{~min}$ at $0^{\circ} \mathrm{C}$, phenylmethylsulfonyl fluoride was added to a final concentration of $1 \mathrm{mM}$. Samples were further incubated for $10 \mathrm{~min}$ at $0^{\circ} \mathrm{C}$. Mitochondria were then reisolated by centrifugation for $12 \mathrm{~min}$ at $18000 \times g$.

\section{Assessment of import of $P_{i} C$}

by hydroxyapatite chromatography

Lysis of mitochondria and passage of samples over hydroxyapatite were performed as previously described [30-
32]. $\mathrm{P}_{\mathrm{i}} \mathrm{C}$ was precipitated from the hydroxyapatite eluate with cold acetone at $-20^{\circ} \mathrm{C}$.

\section{Sequencing}

The precursor of $\mathrm{P}_{\mathrm{i}} \mathrm{C}$ was synthesized in reticulocyte lysate in the presence of $\left[{ }^{3} \mathrm{H}\right]$ glutamic acid. Mature $\mathrm{P}_{i} \mathrm{C}$ was prepared by import into mitochondria ( $4.0 \mathrm{mg}$ protein) in a volume of $1.0 \mathrm{ml}$ and subsequent lysis of reisolated mitochondria in $0.5 \mathrm{ml}$ lysis buffer [ $30 \mathrm{mM}$ sodium phosphate, $\mathrm{pH} 8.2,2 \%$ (mass/vol.) SDS]. After electrophoresis and fluorography, the band of interest was excised, washed in water and extracted by electroelution for $48 \mathrm{~h}$ in a buffer containing $1 \%$ (mass/ vol.) SDS and $30 \mathrm{mM}$ sodium phosphate, $\mathrm{pH} 8.2$. The electroeluted material $\left(25000 \mathrm{cpm}{ }^{3} \mathrm{H}\right]$ glutamic-acid-labeled protein) was subjected to automated solid-phase Edman degradation [33].

\section{Miscellaneous}

Immunoprecipitation of $\mathrm{P}_{\mathrm{i}} \mathrm{C}, \mathrm{SDS} / \mathrm{PAGE}$, fluorography and quantitation of the ${ }^{35} \mathrm{~S}$-labeled $\mathrm{P}_{\mathrm{i}} \mathrm{C}$ were performed as described $[26,34,35]$.

\section{RESULTS}

\section{Synthesis of the precursor of $P_{i} C$ in vitro}

A cDNA-encoding $\mathrm{P}_{\mathrm{i}} \mathrm{C}$ of bovine heart mitochondria was subcloned into $p G E M 4$, resulting in plasmid $p G E M 4 / P_{i} C$, as described in Experimental Procedures (Fig. $1 \mathrm{~A}$ ). By in vitro transcription with SP6 polymerase and translation in rabbit reticulocyte lysates in the presence of $\left[{ }^{35} \mathrm{~S}\right]$ methionine, a protein of $38 \mathrm{kDa}$ was synthesized (Fig. $1 \mathrm{~B}$, lane 1). This putative precursor of $\mathrm{P}_{\mathrm{i}} \mathrm{C}$ was specifically recognized by antibodies prepared against purified mature $\mathrm{P}_{\mathrm{i}} \mathrm{C}$ (Fig. $1 \mathrm{~B}$, lane 2). 
A

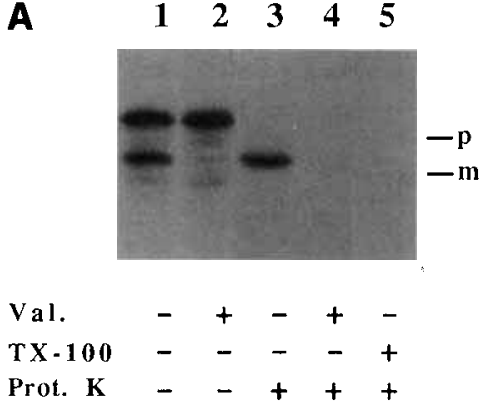

B

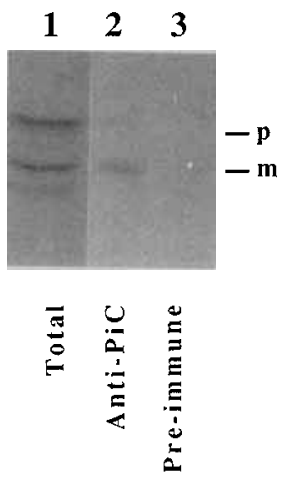

Fig. 2. Import of $P_{i} C$ in vitro. (A) Import of $\mathrm{P}_{\mathrm{i}} \mathrm{C}$ into rat liver mitochondria. The import was performed as described under Experimental Procedures. Reticulocyte lysate containing ${ }^{35} \mathrm{~S}$-labeled $\mathrm{P}_{\mathrm{i}} \mathrm{C}$ and isolated rat liver mitochondria were incubated in the presence of $2 \mathrm{mM}$ NADH (lanes 1,3 and 5) or $1 \mu \mathrm{M}$ valinomycin and $20 \mu \mathrm{M}$ oligomycin (lanes 2 and 4 ) for $15 \mathrm{~min}$ at $25^{\circ} \mathrm{C}$. Lanes 3,4 and 5 were treated with proteinase $\mathrm{K}(25 \mu \mathrm{g} / \mathrm{ml})$ for $20 \mathrm{~min}$ at $0^{\circ} \mathrm{C}$ after the import. Lane 5 received $1 \%$ Triton $\mathrm{X}-100$ before the treatment with protease. The mitochondria (lanes $1-4$ ) were reisolated and analysed by SDS/ PAGE and fluorography. Lane 5 was subjected to precipitation with trichloroacetic acid prior to SDS/PAGE. (B) Immunoprecipitation of precursor and mature $\mathrm{P}_{\mathrm{i}} \mathrm{C}$ after import into rat liver mitochondria. Reticulocyte lysate containing ${ }^{35} \mathrm{~S}$-labeled $\mathrm{P}_{\mathrm{i}} \mathrm{C}$ and isolated rat liver mitochondria were incubated in the presence of $2 \mathrm{mM}$ NADH for $15 \mathrm{~min}$ at $25^{\circ} \mathrm{C}$. The mitochondria were then reisolated, solubilized in Triton X-100-containing buffer (see Experimental Procedures) and divided into three aliquots. Sample 1 was precipitated by acetone, samples 2 and 3 received $10 \mu l$ of anti- $P_{i} C$ serum or preimmune serum, respectively. Immunoprecipitation was then performed as described under Experimental Procedures. Val., valinomycin; TX-100, Triton $\mathrm{X}-100$; Prot. $\mathrm{K}$, proteinase $\mathrm{K}$

\section{Import and assembly of $P_{i} C$ in isolated mitochondria}

To prove that the authentic precursor of $\mathrm{P}_{\mathrm{i}} \mathrm{C}$ had been synthesized, specific import into mitochondria was demonstrated. Reticulocyte lysate containing the precursor of $\mathrm{P}_{\mathrm{i}} \mathrm{C}$ was incubated with energized rat liver mitochondria for $15 \mathrm{~min}$ at $25^{\circ} \mathrm{C}$. The mitochondria were then pelleted and the proteins resolved by SDS/PAGE. A fluorograph of the dried gel shows the conversion of $\mathrm{P}_{\mathrm{i}} \mathrm{C}$ precursor to a protein of $33 \mathrm{kDa}$, corresponding to the apparent molecular mass of mature $\mathrm{P}_{i} \mathrm{C}$ (Fig. 2A, lanes 1 and 3). The difference of about $5 \mathrm{kDa}$ in the apparent molecular masses of precursor and mature forms agrees well with the predicted length of the presequence of 49 amino acid residues. The processed form of $\mathrm{P}_{\mathrm{i}} \mathrm{C}$ was imported into mitochondria and protected against externally added proteinase $\mathrm{K}$ (Fig. $2 \mathrm{~A}$, lane 3 ) unless the mitochondria were disrupted by detergent (Fig. 2A, lane 5).

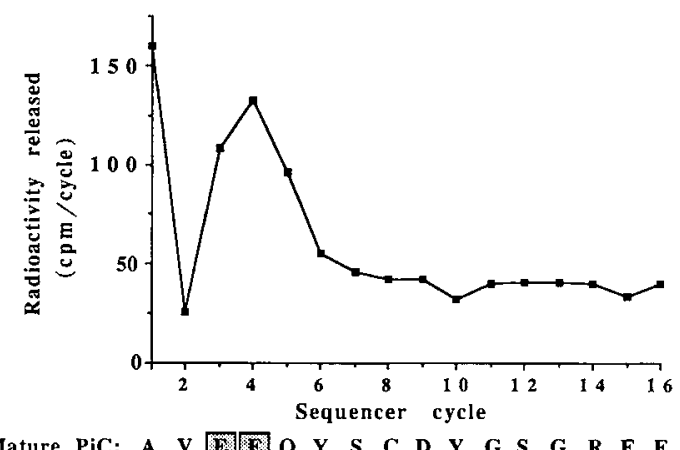

Fig. 3. Sequencing of radioactively labeled imported mature $P_{i} C$. The precursor of $\mathrm{P}_{\mathrm{i}} \mathrm{C}$ was synthesized in rabbit reticulocyte lysate in the presence of $\left[{ }^{3} \mathrm{H}\right]$ glutamic acid and imported into isolated mitochondria. The processed mature protein was then subjected to sequencing as described under Experimental Procedures. The amino-terminal sequence of mature $\mathrm{P}_{\mathrm{i}} \mathrm{C}$, deduced from direct amino acid analysis of the purified protein, is displayed in the one-letter code. Glutamate residues were found at positions 3 and 4 . Radioactivity found in degradation step 1 is merely due to adsorbed (but not covalently bound) material

The precursor associated with mitochondria was digested by proteinase $\mathrm{K}$, indicating that it had not been fully imported. Dissipation of the mitochondrial membrane potential by the potassium ionophore valinomycin completely blocked the import of $\mathrm{P}_{\mathrm{i}} \mathrm{C}$, demonstrating that the import depended on an energized inner membrane, as was found with all other precursor proteins imported into the mitochondrial inner membrane or matrix (Fig. 2A, lanes 2 and 4) [9, 10, 21]. (Oligomycin was included to prevent a decrease of ATP levels and the generation of a membrane potential via the $\mathrm{F}_{0} \mathrm{~F}_{1}$-ATPase.) Both the precursor and mature form of $\mathrm{P}_{\mathrm{i}} \mathrm{C}$ were immunoprecipitated with anti- $\mathrm{P}_{\mathrm{i}} \mathrm{C}$ antibodies (Fig. $2 \mathrm{~B}$, lane 2). No reactivity was found with preimmune serum (Fig. $2 \mathrm{~B}$, lane 3 ).

The precursor of $\mathrm{P}_{\mathrm{j}} \mathrm{C}$ was similarly imported into isolated bovine heart mitochondria, but not into mitochondria from $N$. crassa or the yeast $S$. cerevisiae (data not shown). This indicates a high specificity for recognition of the $\mathrm{P}_{\mathrm{i}} \mathrm{C}$ precursor by mammalian mitochondria. In contrast, several other precursor proteins such as the ADP/ATP carrier, the $F_{0}$-ATPase subunit 9 and ornithine transcarbamylase had previously been found to be efficiently imported into both mammalian and fungal mitochondria $[21,26,36]$.

To determine whether the correct mature form had been produced after import and processing of the $\mathrm{P}_{\mathrm{i}} \mathrm{C}$ precursor by rat liver mitochondria, we determined the processing site by sequencing the mature radioactively labeled $\mathrm{P}_{\mathrm{i}} \mathrm{C}$ protein. The $\mathrm{P}_{\mathrm{i}} \mathrm{C}$ precursor was synthesized in reticulocyte lysate containing $\left[{ }^{3} \mathrm{H}\right]$ glutamic acid. After import into rat liver mitochondria, the mature $\mathrm{P}_{\mathrm{i}} \mathrm{C}$ was obtained by electroelution from SDS/ polyacrylamide gels and subjected to automated solid-phase Edman degradation. Fig. 3 shows the sequence of the mature protein. We observed peaks at position 3 (Glu3) and at position 4 (Glu4). This demonstrates that the processing site is after the amino acid residue at position 49 of the precursor. Thus, the amino-terminus of the mature $\mathrm{P}_{\mathrm{i}} \mathrm{C}$, generated during import and processing by rat liver mitochondria, is identical to the amino-terminus of the mature $\mathrm{P}_{\mathrm{i}} \mathrm{C}$ purified by hydroxyapatite chromatography from solubilized bovine heart mitochondria [37, 38] (V. Zara, unpublished results).

In order to analyse whether $\mathrm{P}_{\mathrm{i}} \mathrm{C}$ was imported to its functional location, we made use of a unique property of the 


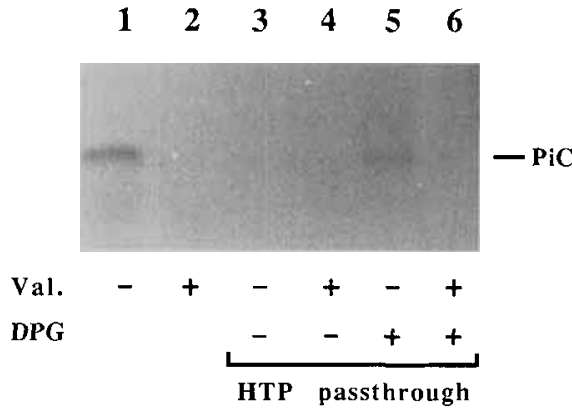

Fig. 4. Assembly of in vitro imported $P_{i} C$. Import of the $\mathrm{P}_{\mathrm{i}} \mathrm{C}$ precursor into mitochondria in the presence of NADH (lanes 1,3 and 5) or valinomycin (lanes 2, 4 and 6) was performed as described under Experimental Procedures. The mitochondria were reisolated and treated as follows: samples 1 and 2 were treated with proteinase $\mathrm{K}$ $(25 \mu \mathrm{g} / \mathrm{ml})$ for $20 \mathrm{~min}$ at $0^{\circ} \mathrm{C}$; samples $3-6$ were solubilized with Triton X-114 buffer in the presence (samples 5 and 6 ) or in the absence (samples 3 and 4 ) of $5 \mathrm{mg} / \mathrm{ml}$ of cardiolipin, then chromatographed on hydroxyapatite [30-32]. Analysis of reisolated mitochondria and of acetone-precipitated eluates was performed by SDS/PAGE and fluorography. DPG, D-glycerate 2,3-bisphosphate; HTP, hydroxyapatite; Val., valinomycin

mature $\mathrm{P}_{\mathrm{i}} \mathrm{C} . \mathrm{P}_{\mathrm{i}} \mathrm{C}$ can be purified by a one-step chromatography by passing it over hydroxyapatite in the presence of cardiolipin [31]. In contrast, without added cardiolipin, $\mathrm{P}_{\mathrm{i}} \mathrm{C}$ is absent from the hydroxyapatite eluate (at a mitochondrial protein concentration of $1-3 \mathrm{mg} / \mathrm{ml}$ ). Fig. 4 shows that $\mathrm{P}_{\mathrm{i}} \mathrm{C}$ imported in vitro (lane 1) bound to hydroxyapatite in the absence of cardiolipin (lane 3) and was eluted in the presence of $5 \mathrm{mg} / \mathrm{ml}$ cardiolipin (lane 5). The non-imported precursor form of $\mathrm{P}_{\mathrm{i}} \mathrm{C}$ was retained by hydroxyapatite even in the presence of $5 \mathrm{mg} /$ $\mathrm{ml}$ cardiolipin (compare lanes 3 and 5 of Fig. 4 to lane 1 of Fig. 2A; data not shown). We conclude that $\mathrm{P}_{\mathrm{i}} \mathrm{C}$ can be expressed in vitro and specifically imported and assembled in mitochondria.

\section{Characteristics of the import pathway of $P_{i} C$}

Fig. $5 \mathrm{~A}$ shows a time course for the import of $\mathrm{P}_{\mathrm{i}} \mathrm{C}$ at $25^{\circ} \mathrm{C}$ that is comparable to those of other mitochondrial precursor proteins in vitro [35]. The import rate was linearly dependent on the time of incubation up to at least $15 \mathrm{~min}$. For the experiment shown in Fig. 5B, the import of $\mathrm{P}_{\mathrm{i}} \mathrm{C}$ was performed for $15 \mathrm{~min}$ at different temperatures and evaluated by an Arrhenius plot. There was a linear dependence between $\log$ (import rate) and $1 / T$. The activation energy derived was $114 \mathrm{~kJ} / \mathrm{mol}(27 \mathrm{kcal} / \mathrm{mol})$.

What are the energy sources that drive the transport of $\mathrm{P}_{\mathrm{i}} \mathrm{C}$ into mitochondria? In Fig. 2 we showed that a potential across the inner membrane was required. Hydrolysis of ATP is necessary for the import of a number of mitochondrial precursor proteins [39-42]. To directly test if ATP was required for the import of $\mathrm{P}_{\mathrm{i}} \mathrm{C}$, the reticulocyte lysate containing $\mathrm{P}_{\mathrm{i}} \mathrm{C}$ was depleted of endogenous ATP and ADP by incubation with apyrase (an ATPase and ADPase from potato). Oligomycin was included to prevent synthesis of ATP and subsequent dissipation of the membrane potential by $F_{0} F_{1}$ ATPase [39]. Lane 2 of Fig. 6 shows that removal of ATP led to a block in $\mathrm{P}_{\mathrm{i}} \mathrm{C}$ import. Re-addition of ATP, but not of GTP, restored the import (Fig. 6, lanes 3-6), indicating that the import of $\mathrm{P}_{j} \mathrm{C}$ depended on the addition of ATP.

Translocation of $\mathrm{P}_{\mathrm{i}} \mathrm{C}$ through sites of close contact between mitochondrial outer and inner membranes (translo-
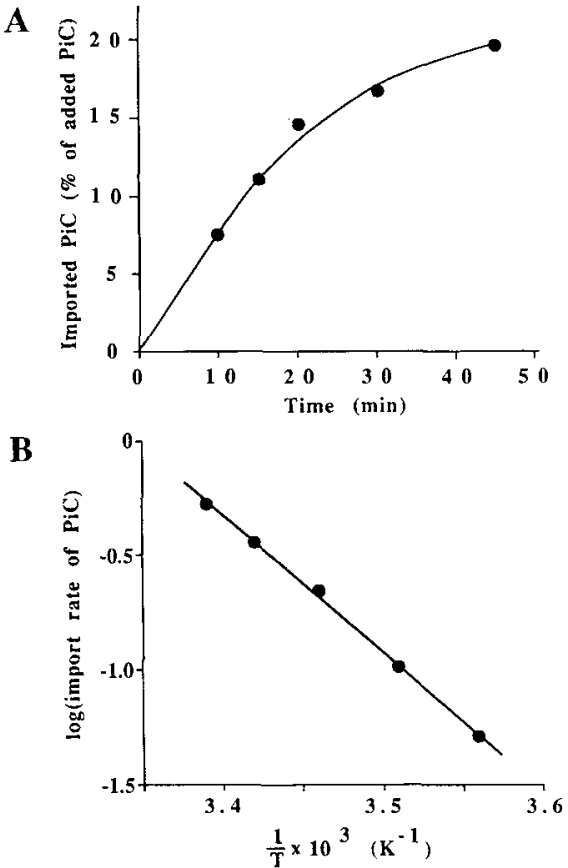

Fig. 5. Temperature dependence of the import of $P_{i} C$. (A) Kinetics of transfer of $P_{i} C$ into mitochondria. Import of $\mathrm{P}_{\mathrm{i}} \mathrm{C}$ synthesized in reticulocyte lysate into mitochondria was performed at $25^{\circ} \mathrm{C}$ for the times indicated as described in the legend of Fig. 2. The amount of ${ }^{35} \mathrm{~S}$-labeled $\mathrm{P}_{\mathrm{i}} \mathrm{C}$ transferred into a proteinase-K-resistant location was determined. The reisolated mitochondria were analysed by SDS PAGE and fluorography. Imported $\mathrm{P}_{\mathrm{i}} \mathrm{C}$ was quantified by laser densitometry [35]. The total amount of radiolabeled $\mathrm{P}_{\mathrm{i}} \mathrm{C}$ added to the import reaction was set to $100 \%$. (B) Arrhenius plot of the temperature dependence of the import of $\mathrm{P}_{\mathrm{i}} \mathrm{C}$ into mitochondria. Import of $\mathrm{P}_{\mathrm{i}} \mathrm{C}$ into mitochondria was performed at the indicated temperatures for $15 \mathrm{~min}$ as described in the legend of Fig. 2. The rates of import were calculated as described for (A). Import rate of $1,1 \%$ imported $\mathrm{P}_{\mathrm{i}} \mathrm{C} / \mathrm{min}$

cation contact sites) was investigated [43-47]. When the import reaction was performed at low temperature $\left(8^{\circ} \mathrm{C}\right)$ the precursor of $\mathrm{P}_{\mathrm{i}} \mathrm{C}$ associated with mitochondria, yet remained accessible to externally added protease (Fig. 7) under conditions where the mitochondrial membranes remained intact $[29,48,49]$. The membrane potential was then dissipated by addition of valinomycin and a second incubation at $25^{\circ} \mathrm{C}$ was performed. $\mathrm{P}_{\mathrm{i}} \mathrm{C}$ was thereby processed and imported into mitochondria as assessed by its protection against proteolysis by proteinase K (Fig. 7). Since the presence of a membrane potential is a prerequisite for the entry of precursor proteins into the inner membrane (Fig. 2A) [43, 50], the precursor of $\mathrm{P}_{\mathrm{i}} \mathrm{C}$ accumulated at $8^{\circ} \mathrm{C}$ must have been in an intermediate location. The precursor must have been beyond the $\Delta \Psi$-dependent step, i.e. it had entered the inner membrane. The protease accessibility demonstrates that a portion of the precursor was located outside the outer membrane. We conclude that the intermediate of $\mathrm{P}_{\mathrm{i}} \mathrm{C}$, observed at $8^{\circ} \mathrm{C}$, bridges both mitochondrial membranes, thereby spanning contact sites $[43$, 50]. The chase of the precursor to the processed and fully imported form confirms that a true translocation intermediate had been generated.

\section{DISCUSSION}

We report here that the bovine $\mathrm{P}_{\mathrm{i}} \mathrm{C}$ is synthesized as precursor protein carrying an amino-terminal extension sequence 


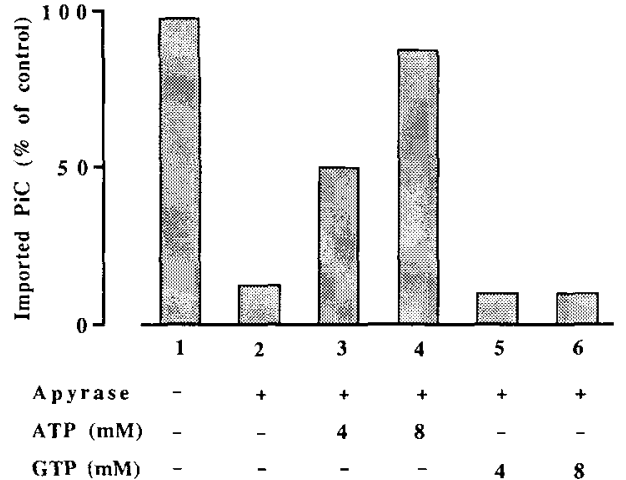

Fig. 6. Import of $P_{i} C$ requires $A T P$. Reticulocyte lysate containing $\mathrm{P}_{\mathrm{i}} \mathrm{C}$ was treated for $15 \mathrm{~min}$ at $25^{\circ} \mathrm{C}$ with apyrase $(0.5$ units $/ \mathrm{ml}$ in samples $2-6$ ) or an apyrase preparation that had been heated to $95^{\circ} \mathrm{C}$ for $10 \mathrm{~min}$ prior to use (corresponding to $0.5 \mathrm{units} / \mathrm{ml}$; sample 1). Isolated mitochondria, $\mathrm{NADH}$ and oligomycin were added. Samples 3 and 4 received ATP and samples 5 and 6 GTP. After incubation for $15 \mathrm{~min}$ at $25^{\circ} \mathrm{C}$, the samples were treated with proteinase $\mathrm{K}(25 \mu \mathrm{g} / \mathrm{ml})$ for $20 \mathrm{~min}$ at $0^{\circ} \mathrm{C}$. Then the mitochondria were reisolated and analysed by SDS/PAGE, fluorography and densitometry. The amount of $\mathrm{P}_{\mathrm{i}} \mathrm{C}$ imported without treatment with apyrase was set to $100 \%$

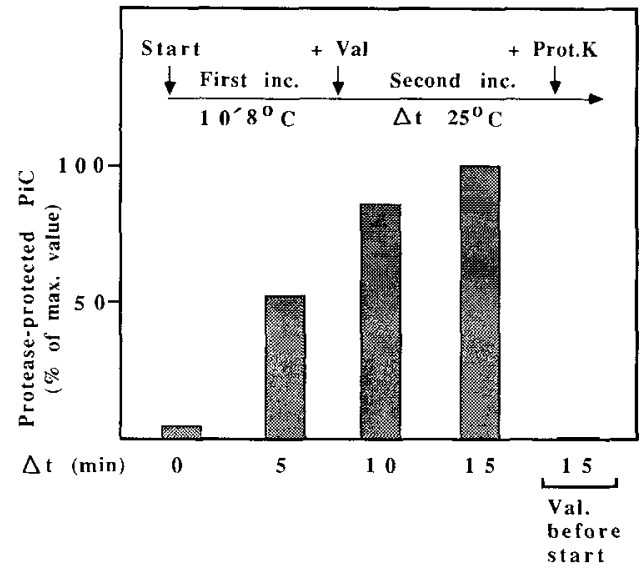

Fig. 7. The precursor of $P_{i} C$ is imported via contact sites. Reticulocyte lysate, mitochondria and NADH were incubated for 10 min at $8^{\circ} \mathrm{C}$. $1 \mu \mathrm{M}$ valinomycin was added and a second incubation at $25^{\circ} \mathrm{C}$ was performed for the indicated times. One sample received valinomycin before the first incubation. After the second incubation, the samples were treated with proteinase $\mathrm{K}(25 \mu \mathrm{g} / \mathrm{ml})$. The mitochondria were reisolated and analysed by SDS/PAGE, fluorography and densitometry. The amount of $\mathrm{P}_{\mathrm{i}} \mathrm{C}$ imported after $15 \mathrm{~min}$ at $25^{\circ} \mathrm{C}$ was set to $100 \%$. Val., valinomycin; inc., incubation; Prot. $\mathrm{K}$, proteinase $\mathrm{K}$

(presequence). In contrast, the other members of the mitochondrial carrier family analysed so far such as the ADP/ATP carrier, the uncoupling protein and the oxoglutarate carrier, are synthesized without a presequence. Analysis of the transport pathway of the $\mathrm{P}_{\mathrm{j}} \mathrm{C}$ precursor revealed the characteristics of general mitochondrial import. The import of $\mathrm{P}_{i} \mathrm{C}$ into rat liver and bovine heart mitochondria required the presence of ATP (the requirement for ATP was specific because the addition of GTP did not restore the import of $\mathrm{P}_{\mathrm{i}} \mathrm{C}$ into mitochondria). The import of $\mathrm{P}_{\mathrm{i}} \mathrm{C}$ also required the membrane potential, $\Delta \Psi$, across the inner membrane and occurred at membrane contact sites between outer and inner membranes, the major site for mitochondrial protein uptake. The imported protein was processed, whereby the correct amino-terminus of the mature protein was generated, demonstrating that the entire 49-amino-acid-residue presequence was removed. Finally, $\mathrm{P}_{\mathrm{i}} \mathrm{C}$ was correctly assembled. Assay for assembly of $\mathrm{P}_{\mathrm{i}} \mathrm{C}$ imported in vitro, binding to hydroxyapatite at low protein concentration and release in the presence of cardiolipin is highly specific; a similar assay for assembly of low amounts of proteins imported in vitro was previously only reported for the ADP/ATP carrier [32].

The $\mathrm{P}_{\mathrm{i}} \mathrm{C}$ precursor was not imported into mitochondria from yeast and $N$. crassa, suggesting that the import of bovine $\mathrm{P}_{\mathrm{i}} \mathrm{C}$ is restricted to mammalian mitochondria. This is probably due to a different specificity of the recognition machinery of mammalian and fungal mitochondria. Additionally, we have found that the purified matrix processing peptidase from $N$. crassa [51] was not able to process the bovine $\mathrm{P}_{\mathrm{i}} \mathrm{C}$ precursor, while a matrix fraction derived from rat liver mitochondria specifically removed the presequence of $\mathrm{P}_{\mathrm{i}} \mathrm{C}$ (V. Zara, unpublished results).

In summary, the biogenesis pathway of mammalian $\mathrm{P}_{\mathrm{i}} \mathrm{C}$ is unusual in comparison with that of the other mitochondrial carriers studied so far, as it involves the synthesis of a cleavable amino-terminal presequence. Obviously members of this family of homologous proteins have developed different ways of mitochondrial targeting. The exact nature of the targeting signals located in the mature parts of the ADP/ATP carrier, the uncoupling protein, and the oxoglutarate carrier is unknown, although preliminary evidence suggests the presence of at least three non-coherent internal signal sequences [5255]. Future studies will have to identify these putative targeting sequences and compare them to the corresponding regions in $\mathrm{P}_{\mathrm{i}} \mathrm{C}$. It may be speculated that the putative internal signals of $\mathrm{P}_{\mathrm{i}} \mathrm{C}$ were not sufficient to direct efficient import of the precursor. Among the possible functions of the presequence of $\mathrm{P}_{\mathrm{i}} \mathrm{C}$ are involvement in interaction with cytosolic cofactors [56] and mitochondrial surface receptors $[57,58]$, and the response to the membrane potential across the inner membrane (negative inside) [27].

By employing anti-idiotypic antibodies, which were raised using a synthetic mitochondrial presequence, Blobel and colleagues identified a $32 \mathrm{kDa}$ protein from yeast mitochondria (p32) as a putative import receptor [17]. $F_{a b}$ fragments directed against p32 inhibited protein import into isolated mitochondria, indicating that the receptor was exposed on the mitochondrial surface, i.e. represented an outer-membrane protein. Unexpectedly, the primary sequence of $\mathrm{p} 32$ was found to be identical to that of the yeast $\mathrm{P}_{\mathrm{i}} \mathrm{C}[18-20]$. It was thus speculated that the cloned proteins reported to be the $\mathrm{P}_{\mathrm{i}} \mathrm{C}$ were not located in the mitochondrial inner membrane and in fact should not function as $\mathrm{P}_{\mathrm{i}} \mathrm{C}$ [18]. Our results show the $\Delta \Psi$ dependent import and proteolytic processing of mammalian $\mathrm{P}_{\mathrm{i}} \mathrm{C}$, clearly excluding an outer-membrane location of $\mathrm{P}_{\mathrm{i}} \mathrm{C}$, since outer-membrane proteins do not carry cleavable extension sequences and are imported without a requirement for $\Delta \Psi[9,21,58,59]$. Furthermore, we demonstrate that the cloned $\mathrm{P}_{\mathrm{i}} \mathrm{C}$ acquires specific properties of native $\mathrm{P}_{\mathrm{i}} \mathrm{C}$ (passage over hydroxyapatite in the presence of cardiolipin [31]) after import into mitochondria, confirming that indeed the authentic $\mathrm{P}_{\mathrm{i}} \mathrm{C}$ had been cloned. A possible explanation is that the anti-p32 antibodies recognize several members of a family of carrier proteins some of which are in the outer membrane and some in the inner membrane. Secondly, the anti-p32 antibodies might recognize some low-abundance outer-membrane proteins in addition to $\mathrm{p} 32$. In fact, the $38 \mathrm{kDa}$ protein, MOM 38 , that forms part of the general insertion site in the outer mem- 
brane, contains a sequence of about 70 amino acid residues with remarkable similarity to $\mathrm{P}_{\mathrm{i}} \mathrm{C}$ [59]. As MOM 38 is about $30-100$-fold less abundant than $\mathrm{p} 32 / \mathrm{P}_{\mathrm{i}} \mathrm{C}[19,59]$, some antibody preparations that are apparently specifically directed against $\mathrm{p} 32 / \mathrm{P}_{\mathrm{i}} \mathrm{C}$ could also recognize MOM38 and thereby inhibit the import of precursor proteins. In any case, unravelling the exact relation between the outer-membrane import receptor described by Pain et al. [17] and the innermembrane $\mathrm{P}_{\mathrm{i}} \mathrm{C}$ will be a major challenge in the analysis of mitochondrial protein uptake and mitochondrial structure.

We are very grateful to Dr. John E. Walker (MRC, Cambridge, UK) for providing a cDNA clone of bovine $\mathrm{P}_{\mathrm{i}} \mathrm{C}$. This study was supported by the Deutsche Forschungsgemeinschaft (Sonderforschungsbereich 184, projects B1 and Z2), the Ministero dell'Università e della Ricerca Scientifica e Tecnologica (MURST), the target project Biotechnology and Bioinstrumentation of Consiglio Nazionale delle Ricerche (CNR), the Genzentrum München, and the Fonds der Chemischen Industrie.

\section{REFERENCES}

1. LaNoue, K. F. \& Schoolwerth, A. C. (1979) Annu. Rev. Biochem. 48, $871-922$.

2. Meijer, A. J. \& Van Dam, K. (1981) in Membrane transport (Bonting, S. \& De Pont, J., eds) pp. 235-256, Elsevier Press, Amsterdam.

3. Palmieri, F., Prezioso, G., Bisaccia, F., Indiveri, C., Zara, V., De Pinto, V. \& Genchi, G. (1987) in Advances in myochemistry (Benzi, G., ed.) pp. 87-104, John Libbey, Eurotext Ltd.

4. Kramer, R. \& Palmieri, F. (1989) Biochim. Biophys. Acta 974, 123

5. Aquila, H., Misra, D., Eulitz, M.\& Klingenberg, M. (1982) Hoppe Seyler's Z. Physiol. Chem. 363, 345-349.

6. Aquila, H., Link, T. A. \& Klingenberg, M. (1985) EMBO J. 4, $2369-2376$.

7. Runswick, M. J., Powell, S. J., Nyren, P. \& Walker, J. E. (1987) EMBO J. 6, 1367-1373.

8. Runswick, M. J., Walker, J. E., Bisaccia, F., Iacobazzi, V. \& Palmieri, F. (1990) Biochemistry 29, $11033-11040$

9. Attardi, G. \& Schatz, G. (1988) Annu. Rev. Cell Biol. 4, $289-$ 333.

10. Pfanner, N. \& Neupert, W. (1990) Annu. Rev. Biochem. 59, 331 353.

11. Zimmermann, R., Paluch, U., Sprinzl, M. \& Neupert, W. (1979) Eur. J. Biochem. 99, 247-252.

12. Freeman, K. B., Chien, S.-M., Litchfield, D. \& Patel, H. V. (1983) FEBS Lett. 158, 325-330.

13. Ricquier, D., Thibault, J., Bouillaud, F. \& Kuster, Y. (1983) J. Biol. Chem. 258, 6675-6677.

14. Arends, H. \& Sebald, W. (1984) EMBO J. 3, 377-382.

15. Ridley, R. G., Patel, H. V., Gerber, G. E., Morton, R. C. \& Freeman, K. B. (1986) Nucleic Acids Res. 14, 4025-4035.

16. Ferreira, G. C., Pratt, R. D. \& Pedersen, P. L. (1989) J. Biol. Chem. 264, 15628-15633.

17. Pain, D., Murakami, H. \& Blobel, G. (1990) Nature 347, $444-$ 449.

18. Murakami, H., Blobel, G. \& Pain, D. (1990) Nature 347, $488-$ 491.

19. Phelps, A., Schobert, C. \& Wohlrab, H. (1991) Biochemistry 30, $248-252$

20. Meyer, D. I. (1990) Nature 347, 424-425.

21. Hartl, F.-U., Pfanner, N., Nicholson, D. W.\& Neupert, W. (1989) Biochim. Biophys. Acta 988, 1-45.

22. Melton, D. A., Krieg, P. A., Rebagliati, M. R., Maniatis, T., Zinn, K. \& Green, M. R. (1984) Nucleic Acids Res. 12, 70357056
23. Pelham, H. R. B. \& Jackson, R. J. (1976) Eur. J. Biochem. 67, $247-256$

24. Low, H. \& Vallin, I. (1963) Biochim. Biophys. Acta 69, $361-$ 370 .

25. Goglia, F., Liverini, G., Lanni, A., Iossa, S. \& Barletta, A. (1988) Biochem. Biophys. Res. Comm. 151, $1241-1249$.

26. Schleyer, M., Schmidt, B. \& Neupert, W. (1982) Eur. J. Biochem. $125,109-116$

27. Pfanner, N. \& Neupert, W. (1985) EMBO J. 4, 2819-2825.

28. Daum, G., Gasser, S. M. \& Schatz, G. (1982) J. Biol. Chem. 257, $13075-13080$.

29. Hartl, F.-U., Ostermann, J., Guiard, B. \& Neupert, W. (1987) Cell 51,1027-1037.

30. Klingenberg, M., Aquila, H. \& Riccio, P. (1979) Methods Enzymol. 56, 407-414.

31. Bisaccia, F. \& Palmieri, F. (1984) Biochim. Biophys. Acta 766, $386-394$

32. Schleyer, M. \& Neupert, W. (1984) J. Biol. Chem. 259, $3487-$ 3491

33. Wachter, E., Machleidt, W., Hofner, H. \& Otto, J. (1973) FEBS Lett. 53, 97-102.

34. Chamberlain, J. P. (1979) Anal. Biochem. 98, 132-135.

35. Pfanner, N., Müller, H. K., Harmey, M. A. \& Neupert, W. (1987) $E M B O J .6,3449-3454$.

36. Cheng, M. K., Pollock, R. A., Hendrick, J. R. \& Horwich, A. L. (1987) Proc. Natl Acad. Sci. USA 84, 4063-4067.

37. Kolbe, H. V. J. \& Wohlrab, H. (1985) J. Biol. Chem. 260, $15899-$ 15906

38. Aquila, H., Link, T. A. \& Klingenberg, M. (1987) FEBS Lett $212,1-9$.

39. Pfanner, N. \& Neupert, W. (1986) FEBS Lett. 209, 152 - 156.

40. Pfanner, N., Tropschug, M. \& Neupert, W. (1987) Cell 49, $815-$ 823.

41. Chen, W.-J. \& Douglas, M. G. (1987) Cell 49,651-658

42. Eilers, M., Oppliger, W. \& Schatz, G. (1987) EMBO J. 6, $1073-$ 1077.

43. Schleyer, M. \& Neupert, W. (1985) Cell 43, 339-350.

44. Schwaiger, M., Herzog, V. \& Neupert, W. (1987) J. Cell Biol. 105 $235-246$

45. Pfanner, N., Hartl, F.-U., Guiard, B. \& Neupert, W. (1987) Eur J. Biochem. 169, 289-293.

46. Vestweber, D. \& Schatz, G. (1988) J. Cell Biol. 107, 2037-2043.

47. Rassow, J., Guiard, B., Wienhues, U., Herzog, V., Hartl, F.-U. \& Neupert, W. (1989) J. Cell Biol. 109, $1421-1428$.

48. Hartl, F.-U., Schmidt, B., Wachter, E., Weiss, H. \& Neupert, W. (1986) Cell 47, 939-951.

49. Nicholson, D. W., Hergersberg, C. \& Neupert, W. (1988) J. Biol. Chem. 263, 19034-19042.

50. Pfanner, N. \& Neupert, W. (1987) J. Biol. Chem. 262, 7528 7536.

51. Hawlitschek, G., Schneider, H., Schmidt, B., Tropschug, M., Hartl, F.-U. \& Neupert, W. (1988) Cell 53, 795-806.

52. Adrian, G. S., McGammon, M. T., Montgomery, D. L. \& Douglas, M. G. (1986) Mol. Cell. Biol. 6, 626-634.

53. Pfanner, N., Hoeben, P., Tropschug, M. \& Neupert, W. (1987) $J$. Biol. Chem. 262, 14851-14854.

54. Liu, X., Bell, A. W., Freeman, K. B. \& Shore, G. C. (1988) J.Cell Biol. 107, 503-509.

55. Smagula, C. S. \& Douglas, M. G. (1988) J. Cell. Biochem. 36, $323-327$.

56. Murakami, K. \& Mori, M. (1990) EMBO J. 9, 3201-3208.

57. Söllner, T., Griffiths, G., Pfaller, R., Pfanner, N. \& Neupert, W. (1989) Cell 59, $1061-1070$.

58. Söliner, T., Pfaller, R., Griffiths, G., Pfanner, N. \& Neupert, W. (1990) Cell 62,107-115.

59. Kiebler, M., Pfaller, R., Söllner, T., Griffiths, G., Horstmann, H., Pfanner, N. \& Neupert, W. (1990) Nature 348, 610-617. 